\title{
A CHO mutant, UV40, that is sensitive to diverse mutagens and represents a new complementation group of mitomycin $\mathrm{C}$ sensitivity
}

\author{
David B. Busch ${ }^{\text {a, }}{ }^{*}$, Małgorzata Z. Zdzienicka ${ }^{\text {b }}$, Adayapalam T. Natarajan ${ }^{\text {, }}$, \\ Nigel J. Jones ${ }^{c}$, Wilhemina J.I. Overkamp ${ }^{b}$, Andrew Collins ${ }^{d}$, David L. Mitchell ${ }^{e}$, \\ Miria Stefanini ${ }^{\mathrm{f}}$, Elena Botta ${ }^{\mathrm{f}}$, Roberta Bliss Albert ${ }^{\mathrm{a}}$, Nan Liu ${ }^{\mathrm{g}}$, \\ Deborah A. White ${ }^{\text {a }}$, Alain J. van Gool ${ }^{\text {h }}$, Larry H. Thompson ${ }^{\mathrm{g}}$ \\ "Armed Forces Institute of Pathology, Washington, DC 20306-6000, USA \\ ${ }^{\mathrm{b}}$ Department of Genetics, Radiation Genetics and Chemical Mutagenesis and J.A. Cohen Institute, Leiden Unicersity, Wassenaarseweg 72, \\ P.O. Box 9503, 2300 RA Leiden. The Netherlands \\ 'Department of Genetics and Microbiology, Donnan Laboratories, School of Life Sciences, Unicersity of Licerpool. P.O. Box 147. \\ Licerpool L69 $3 B X, U K$ \\ ${ }^{\triangleleft}$ Bovd Orr Research Centre. Unicersity of Aberdeen and Rowett Research Institute, Greenburn Road, Bucksburn, Aberdeen, AB2 $9 S B$ \\ Scotland, UK \\ ' Science Park Research Division, MD Anderson Cancer Center, P.O. Box 389, Smithcille, TX 78957, USA \\ ${ }^{\dagger}$ Consiglio Nazionale delle Ricerche-Istituto di Genetica Biochimica ed Evoluzionistica, ía Abbiategrasso 207, 27100 Patia, Italy \\ Biomedical Sciences Dic ision, Lawrence Livermore National Laboratory, P.O. Box 5507, Litermore, CA 94550, USA \\ ' Department of Cell Biology and Genetics, Erasmus Unic ersity, P.O. Box 1738. 3000 DR Rotterdam. The Netherlands
}

Received 21 August 1995: revised 23 February 1996: accepted 27 February 1996

\begin{abstract}
A new mitomycin C (MMC)-sensitive rodent line, UV40. has been identified in the collection of ultraviolet light- (UV-) sensitive mutants of Chinese hamster ovary $(\mathrm{CHO})$ cells isolated at the previous Facility for Automated Experiments in Cell Biology (FAECB). It was isolated from an UV mutant hunt using mutagenesis of AA8 cells with the DNA intercalating frameshift mutagen ICR 170. It is complemented by CHO-UV-1, irs1, irs3, irs1SF, MC5, V-C8 and V-H4 with respect to its MMC sensitivity based on cell survival. Despite having approx. $4 \times$ normal UV sensitivity and increased sensitivity to UV inhibition of DNA replication, it has near-normal incision kinetics of UV irradiated DNA, and normal (6-4) photoproducts removal. It also is not hypermutable by UV, and shows near normal levels of UV inhibition of RNA synthesis. UV40 also has approx. $11 \times, 10 \times, 5 \times$ and $2 \times$ AA8 sensitivity to MMC, ethyl methanesulfonate (EMS), methyl methanesulfonate (MMS), and X-rays, respectively. Thus, its defect apparently does not involve nucleotide excision repair but rather another process, possibly in replicating past lesions. The spontaneous chromosomal aberration frequency is elevated to $20 \%$ in
\end{abstract}

\footnotetext{
"Corresponding author. Tel.: 001202 782-2849; Fax: 782-9215/782-7164.
} 
UV40, and the baseline frequency of sister chromatid exchange is also $\sim 4$-fold increased. The phenotype of UV40 appears to differ from all other rodent mutants that have so far been described.

Keywords: DNA repair; Fanconi's ancmia; Mitomycin C; Mutants; Rodent; Ultraviolet light

\section{Introduction}

The collection of ultraviolet light- (UV-) mutant Chinese hamster ovary (CHO) cells from the Facility for Automated Experiments in Cell Biology (FAECB) (Busch, 1980; Busch et al., 1980, 1994) has contributed representatives of several new rodent complementation groups (CGs), including UV24 and UV4I in CGs 3 and 4 (Thompson et al., 1981), and UV135 and UV61 in CGs 5 and 6 (Busch et al., 1994). The FAECB was closed in 1980 due to funding problems (Harris, 1980a,b; Petit, 1980). UV41 was subsequently used to clone the ERCC4 gene (Thompson et al., 1994); UV135 used to clone the ERCC5 gene (Mudgett and MacInnes, 1990); and UV61 used to clone the ERCC6 gene (Troelstra et al., 1990, 1992). The mutant irs $1 \mathrm{SF}$, isolated at the FAECB as an X-ray sensitive clone (Fuller and Painter, 1988), is the sole representative of a mitomycin C (MMC)-sensitive CG of rodent cells (Collins, 1993; Thompson, 1989). irs1SF, like other prototype rodent MMC-sensitive mutants, such as irs1 and V-C8 (Jones et al., 1993; Overkamp et al., 1993), is also sensitive to UV as well as to X-rays and ethyl methanesulfonate (EMS). Until recently, irs 1SF was the only identified CHO FAECB mutant with this pattern of mutagen sensitivity.

UV40 had previously been found not to be in rodent UV CGs $1-3$ and thus to represent a rare UV sensitive CG (Thompson, L.H., unpublished data). Because of its moderate UV sensitivity and poor growth, it was not further characterized until recently. During the complementation assignment of over 70 moderately UV sensitive mutants from this collection (Busch et al., 1994), mutant UV40 was studied further, leading to the discovery that this mutant apparently is not defective in nucleotide excision repair. This finding, along with its unusual near-exponential UV survival curve, and its much higher sensitivity to MMC than to $\mathrm{UV}$, led to an attempt to assign the mutant to one of the known rodent CGs for MMC hypersensitivity. Fusions with representatives of seven CGs of MMC-sensitive rodent cells (Jones, 1994; Overkamp et al., 1993) have led to the discovery that UV40 represents a new group. Characterization of this mutant also shows phenotypic traits that appear unique among mutants reported to date.

\section{Materials and methods}

\subsection{Mutant}

As previously described (Busch. 1980; Busch et al., 1980, 1994), UV40 (FAECB No. 361-114-33) was isolated using the FAECB's semiautomated method following ICR-170 mutagenesis of AA8 cells, $1.0 \mu \mathrm{g} / \mathrm{ml}$ for $18 \mathrm{~h}$. This mutant had a negative Hoechst 33258 mycoplasma test at the AFIP (Armed Forces Institute of Pathology, Walter Reed Army Medical Center, Washington DC).

\subsection{Complementation group assignments}

CG1-6 (CHO) (Busch et al., 1989, 1994; Thompson et al., 1981, 1987) mutant TOR (6-Thioguanine and $O$ uabain Resistant) derivatives UV20TOR, UV5TOR, UV24TOR, UV41TOR, UV135TOR, and UV61TOR and CG8 (L5178Y) (Thompson et al.. 1988) mutant TOR derivative US31TOR were isolated at Livermore. CG7 (V-79) (Zdzienicka et al., 1988) mutant TOR derivative V-B1ITOR was isolated at Leiden. CG9-10 (CHO) (Stefanini et al., 1991) mutant TOR derivatives CHO7PVTOR and CHO4PVTOR were isolated at Pavia. CGIl (CHO) (Riboni et al., 1992) mutant TOR derivative UVSI TOR was isolated at the AFIP from a UVSI culture generously donated by Dr. Akira Yasui. CHO-UV 1 TOR, MC5TOR, irs1TOR, and irs3TOR were isolated from the parental (non-TOR) MMC mutants by N. Jones (Jones et al., 1988; Jones, 1994). irs ITOR was provided to $\mathrm{M}$. Zdzienicka by John Thacker. The V-H4 (Zdzienicka et al., 1990; Studzian et al., 
1994) TOR derivative, and also irsISFTOR and V-C8TOR were isolated at Leiden. CG assignments were performed as previously described for UV studies (Thompson et al., 1981; Busch et al., 1994) as well as for MMC studies (Jones, 1994; Overkamp et al., 1993). UV1 was previously shown to be in a different MMC CG than UV20 and UV41 (Hoy et al., 1985); and UV1, UV20, UV41, irs1, and irs1SF were subsequently all shown to be in different MMC CGs (Jones et al.. 1990).

\subsection{DNA incision assay}

Cells were inoculated at $10^{5}$ per $35 \mathrm{~mm}$ tissue culture dish in $1 \mathrm{ml}$ of Glasgow-modified Minimal Essential Medium with 5\% fetal calf serum and 5\% newborn calf serum in an atmosphere of $6 \% \mathrm{CO}_{2}$ at $37^{\circ} \mathrm{C}$, with addition to the medium of [methyl${ }^{3} \mathrm{H}$ ]thymidine (Amersham, $13.5 \mathrm{Ci} / \mathrm{mmol}$ ) at 0.1 $\mathrm{mCi} / \mathrm{ml}$. After overnight incubation, the medium was replaced with non-radioactive medium. One hour later, the medium was briefly removed for irradiation with $254 \mathrm{~nm} \mathrm{UV}$ at a dose rate of $0.25 \mathrm{~J} / \mathrm{m}^{2}$ per s. One group of dishes received inhibitors $(2 \mathrm{mM}$ hydroxyurea, $0.1 \mathrm{mM}$ 1- $\beta$-D-arabinofuranosylcytosine, and $5 \mathrm{mM}$ aphidicolin), from $30 \mathrm{~min}$ before irradiation until $30 \mathrm{~min}$ afterwards. Inhibitors were added to the remaining dishes at $4 \mathrm{~h}$ after irradiation; incubation with inhibitors then continued for 30 or $60 \mathrm{~min}$. At the end of the incubation period, cells were rinsed with $1 \mathrm{ml}$ of phosphate-buffered saline (PBS) and lysed with $1 \mathrm{ml}$ of alkaline sucrose (5\% sucrose, $0.3 \mathrm{M} \mathrm{NaOH}$, neutralized with $0.25 \mathrm{ml}$ of 1 $\mathrm{M} \mathrm{KH_{2 }} \mathrm{PO}_{4}$ ), and the lysates were sonicated and diluted to $20 \mathrm{ml}$ with $\mathrm{H}_{2} \mathrm{O}$ and $0.05 \%$ sodium lauryl sulfate. The percent of DNA unwound in alkali was mcasured by hydroxyapatite chromatography, and the frequency of DNA breaks calculated as previously described (Squires et al., 1982).

Incubation of UV-irradiated cells with inhibitors of DNA synthesis typically causes an accumulation of DNA breaks, representing DNA repair sites at which incision has occurred but repair synthesis and ligation are prevented. This is the basis of the incision assay, applied here to UV40.

To gain an accurate measure of incision, it is crucial to maximize the inhibition of repair DNA synthesis. Hydroxyurea and 1- $\beta$-D-arabinofurano- sylcytosine cause a greater accumulation of (UV-dependent) DNA breaks than when either is present singly (Collins and Oates, 1987). For the present work, a mixture of hydroxyurea, 1- $\beta-D-$ arabinofuranosylcytosine, and another inhibitor, aphidicolin, was applied. Rather higher levels of DNA breakage may be obtained if the inhibition is well established at the time of irradiation by preincubating cells with inhibitors (Collins et al., 1982).

\section{4. (6-4) photoproducts assay}

The time course of excision of (6-4) photoproducts was studied for UV40 and AA8 as previously described (Mitchell et al., 1988), following $20 \mathrm{~J} / \mathrm{m}^{2}$ of UV.

\subsection{UV inhibition of DNA synthesis}

Cells, incubated at $10^{5}$ per $35 \mathrm{~mm}$ tissue culture dish in $1 \mathrm{ml}$ of the cold medium used in the incision assay, were incubated overnight and then irradiated with $254 \mathrm{~nm} \mathrm{UV}, 0.25 \mathrm{~J} / \mathrm{m}^{2}$, at a range of doses. At intervals, $\left[{ }^{3} \mathrm{H}\right]$ thymidine $(0.1 \mathrm{mCi} / \mathrm{ml})$ was added to sample dishes for $1 \mathrm{~h}$, after which cells were rinsed with PBS and lysed with $1 \mathrm{ml}$ of $0.5 \mathrm{M} \mathrm{NaOH}$. DNA was precipitated by adding $1 \mathrm{ml}$ of $20 \%(\mathrm{w} / \mathrm{v})$ trichloroacetic acid, chilled at least $30 \mathrm{~min}$, and filtered onto glass circles (Whatman GF/C), and radioactivity was measured by scintillation counting. At each time point, incorporation of $\left[{ }^{3} \mathrm{H}\right]$ thymidine into DNA is expressed as a percent of the incorporation in mock-irradiated control cells at corresponding times.

\subsection{UV inhibition of RNA synthesis}

Cells were studied as previously described (Mayne and Lehmann, 1982; Troelstra et al., 1992), using both single-time multiple-dose and single-dose multiple-time experiments, with the following modifications or conditions:

For single-dose multiple-time experiments, cells were incubated overnight $(17 \mathrm{~h})$ with $\left[{ }^{14} \mathrm{C}\right]$ thymidine-containing HEPES buffered Ham Fl0, and then irradiated with $7.5 \mathrm{~J} / \mathrm{m}^{2}$ of UV $(254 \mathrm{~nm})$. They were refed with nonradioactive medium, and then incubated for $1 \mathrm{~h}$ with $\left[{ }^{3} \mathrm{H}\right]$ uridine medium at $0,3,7$, 
and $17 \mathrm{~h}$ after UV. Lysis (confirmed by microscopy) was performed with $0.5 \mathrm{ml} /$ dish of fresh $0.2-0.3 \mathrm{M}$ $\mathrm{NaOH}$, with solution then placed in a $25 \mathrm{ml}$ scintillation vial with $7.5 \mathrm{ml}$ of Packard Hionic Fluor scintillation fluid, and shaken, followed by counting for at least $10 \mathrm{~min} /$ vial using a ${ }^{3} \mathrm{H} /{ }^{14} \mathrm{C}$ dual program. Unirradiated dish ${ }^{3} \mathrm{H} /{ }^{14} \mathrm{C}$ ratio was defined as $100 \%$ for each cell line.

For single-time multiple-dose experiments, cells were rinsed with PBS after $24 \mathrm{~h}$ of $\left[{ }^{14} \mathrm{C}\right]$ thymidine labeling, and irradiated with $0,1,2.5,5,7.5$ and 10 $\mathrm{J} / \mathrm{m}^{2}$ of UV. They were refed with nonradioactive medium and incubated for $17 \mathrm{~h}$. They then were given the $\left[{ }^{3} \mathrm{H}\right]$ uridine pulse, cold medium chase, lysis, and counting as with the multiple-time singledose experiments.

\subsection{UV survival studies}

These were performed as described elsewhere (Busch, 1980; Busch et al., 1980), using the integrating UV irradiator system.

\subsection{EMS, MMC, MMS, and X-ray survival studies}

Treatment conditions were as follows: $\mathrm{X}$-rays, $100 \mathrm{kV}$ treatment with up to $800 \mathrm{rad}(800 \mathrm{cGy})$ for AA8 and $400 \mathrm{rad}$ for UV40 with $3 \mathrm{~Gy} / \mathrm{min}$ dose rate, $8 \mathrm{~mA}$ current, $0.78 \mathrm{~mm} \mathrm{Al} \mathrm{filter;} \mathrm{EMS,} \mathrm{1-h}$ treatment with up to $30 \mathrm{mM}$ for AA8 and $10 \mathrm{mM}$ for UV40; MMC, 24-h treatment with up to $160 \mathrm{ng} / \mathrm{ml}$ for AA8 and up to $10 \mathrm{ng} / \mathrm{ml}$ for UV40; and methyl methanesulfonate (MMS), 1-h treatment with up to 2 $\mathrm{mM}$ for AA8 and $0.5 \mathrm{mM}$ for UV40.

\subsection{UV mutability studies}

UV mutability of AA8 and UV40 to 8-azaadenine (8-AA) resistance $(80 \mathrm{mg} / \mathrm{ml}$ in $\alpha \mathrm{MEM}$ with $10 \%$ dialyzed fetal bovine serum, Gibco) was measured as previously described (Thompson et al., 1980), but with substitution of several $175-\mathrm{cm}^{2}$ tissue culture flasks for each spinner flask. Cultures were grown up to approx. $10^{8}$ cells from aliquots of $<100$ cells and then frozen down in several vials per culture, with one vial used to verify low background of 8-AA-resistant mutant colonies. Expression time was 3 days after irradiation of $1.1 \times 10^{7}$ cells $/ 100-\mathrm{mm}$ dish us- ing the integrating UV irradiator, with effacement by dacron swab of cells on the edge of the dish. $5 \times 10^{5}$ irradiated or control cells were plated in $100-\mathrm{mm}$ dishes with $30 \mathrm{ml}$ of 8 -AA selective medium. UV mutability to 6-thioguanine (6-TG) resistance was performed as previously described (Thompson et al., 1982).

\subsection{Clastogenesis and sister chromatid exchange with $M M C$}

Exponentially growing AA8 and UV40 cells were treated with different concentrations of MMC for 24 $h$. The cells were washed and allowed to recover for $2 \mathrm{~h}$ in normal medium or for $43 \mathrm{~h}$ in medium containing $5 \mathrm{mM}$ bromodeoxyuridine. For estimating frequency of chromosomal aberrations, the cells fixed at $21 \mathrm{~h}$ were stained with $5 \%$ aqueous Giemsa solution for $8 \mathrm{~min}$. One hundred metaphases were scored for each point. Data for chromosomal aberrations are from two separate experiments. Cells fixed at $43 \mathrm{~h}$ were processed for estimating the frequency of SCEs. The slides were stained by FPG (fluorescent plus Giemsa) technique (Perry and Wolff, 1974). Twenty-five cells were scored for each point for determination of the frequencies of SCEs.

\section{Results}

\subsection{General growth characteristics of UV4O}

UV40 cells are noticeably abnormal in terms of their growth properties. They attach inefficiently to plastic and have a rounded appearance; this feature complicates survival measurements based on colony forming ability. They have a plating efficiency of $\sim 50 \%$ compared to $\sim 80 \%$ for AA8 cells, and their doubling time is $18 \mathrm{~h}$ compared to $12 \mathrm{~h}$ for AA8 cells.

\subsection{Profile of sensitivity to standard DNA-damaging agents}

The mutant UV40 was originally isolated as an UV-sensitive mutant. The survival curves shown in Fig. 1A show that this mutant has substantial UV sensitivity. Using the $D_{10}$ values as a simple mea- 

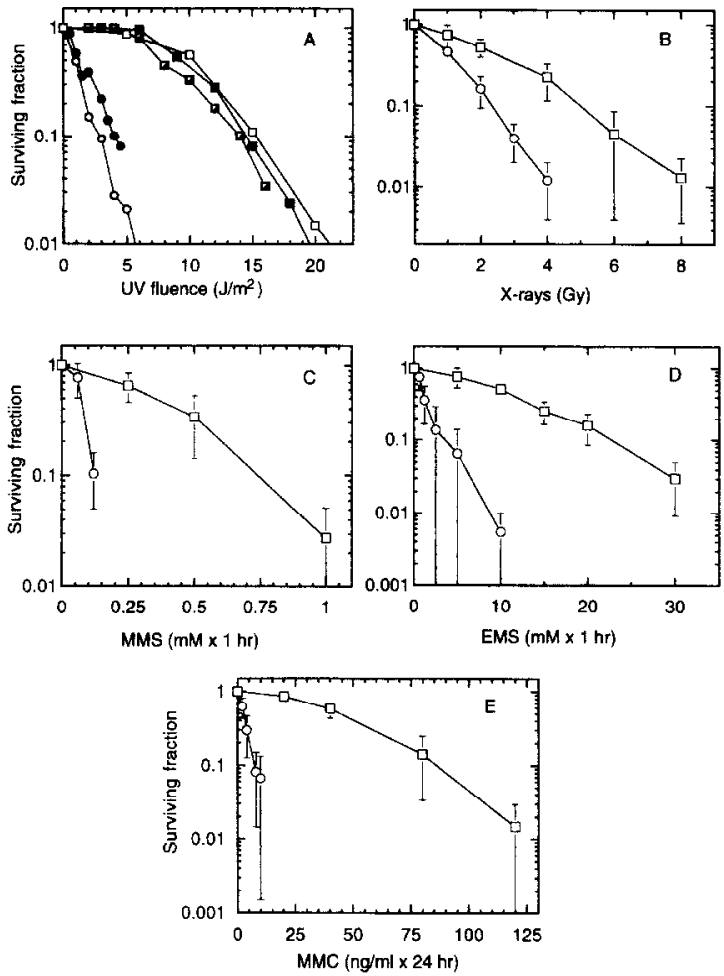

Fig. 1. Hypersensitivity of UV40 cells to killing by various DNA damaging agents. (A) UV irradiation; (B) X-rays; (C) MMS; (D), EMS; (E), MMC. Symbols: AA8 cells, squares; UV40 cells, circles. (A) Different symbols represent different experiments. Cells were exposed to various agents as described in Section 2: Materials and methods.

sure of sensitivity, UV40 is $\sim 4$-fold more sensitive than the parental AA8 cells. It is also noteworthy that there is little or no shoulder on the survival curves of UV40, a feature also seen with the V79 mutant irs1 (Jones et al., 1987). This degree of UV sensitivity is less than that of the mutants belonging to nucleotide-excision-repair complementation groups 1 through 5 (Thompson et al., 1981; Thompson and Carrano, 1983) but is similar to UV61 (Thompson et al., 1989), a mutant in complementation group 6 that appears defective in the preferential repair of active genes (Lommel and Hanawalt, 1991).

To see whether UV40 shows a mutagen sensitivity profile like that of previously described mutants, several other commonly used DNA damaging agents were tested. UV40 is slightly cross-sensitive to X-ray damage (Fig. 1B), showing 2-fold hypersensitivity.
The simple alkylating agents methyl methanesulfonate and ethyl methanesulfonate gave much higher sensitivities, approx. 7-fold and 10-fold, respectively (Fig. IC and D). Finally, a prototype cross-linking agent, MMC, was examined, and this agent also showed a substantial degree of hypersensitivity ( $\sim$ 11-fold) (Fig. 1E). Thus, it is apparent that UV40 has a wide spectrum of DNA damage sensitivity, which is reminiscent of irsl (Jones et al., 1987) although irs 1 has significantly more MMC sensitivity (60-fold).

\subsection{Complementation group analysis}

Given the relatively high sensitivity of UV40 to MMC, it was of interest to determine whether this mutant might belong to the same complementation group as other $\mathrm{MMC}$-sensitive rodent lines. The mutants used in this analysis were from V79 hamster cells (V-C8, V-H4, irs1 and irs3) or from $\mathrm{CHO}$ hamster cells (irs1SF, MC5 and UV1). irs $1 \mathrm{SF}$ and MC5 are derived from the AA8 parental line while UV1 descended from CHO-K1. Fig. 2A shows the results of analyzing hybrids derived from fusions between UV40 with V-C8 and V-H4 lines that carry the 'TOR' drug resistance markers used as previously described (Thompson et al., 1981). The two hybrids were even more MMC resistant than the wild-type parental lines, showing clear complementation. Hybrids formed with UV40 versus irsl and irs 1 SF are shown in Fig. 2B. Again, their resistance was in the range of the wild-type lines. A separate complementation study performed under different MMC exposure conditions was done to test for complementation of UV40 by three other mutants (irs3, MC5, and UV1), which are less sensitive to MMC than the mutants just described (results shown in Fig. 2C). Again, all three hybrid lines were highly resistant to $\mathrm{MMC}$, implying efficient complementation. From these experiments we conclude that UV40 represents a distinct complementation group from the other seven mutants tested here. UV40 was also used to form hybrids with TOR derivatives of each of the 11 established complementation groups of nucleotide excision repair mutants. Hybrids tested for their survival to UV irradiation were resistant, indicating that UV40 does not fall into any of these 11 complementation groups (data not shown). 

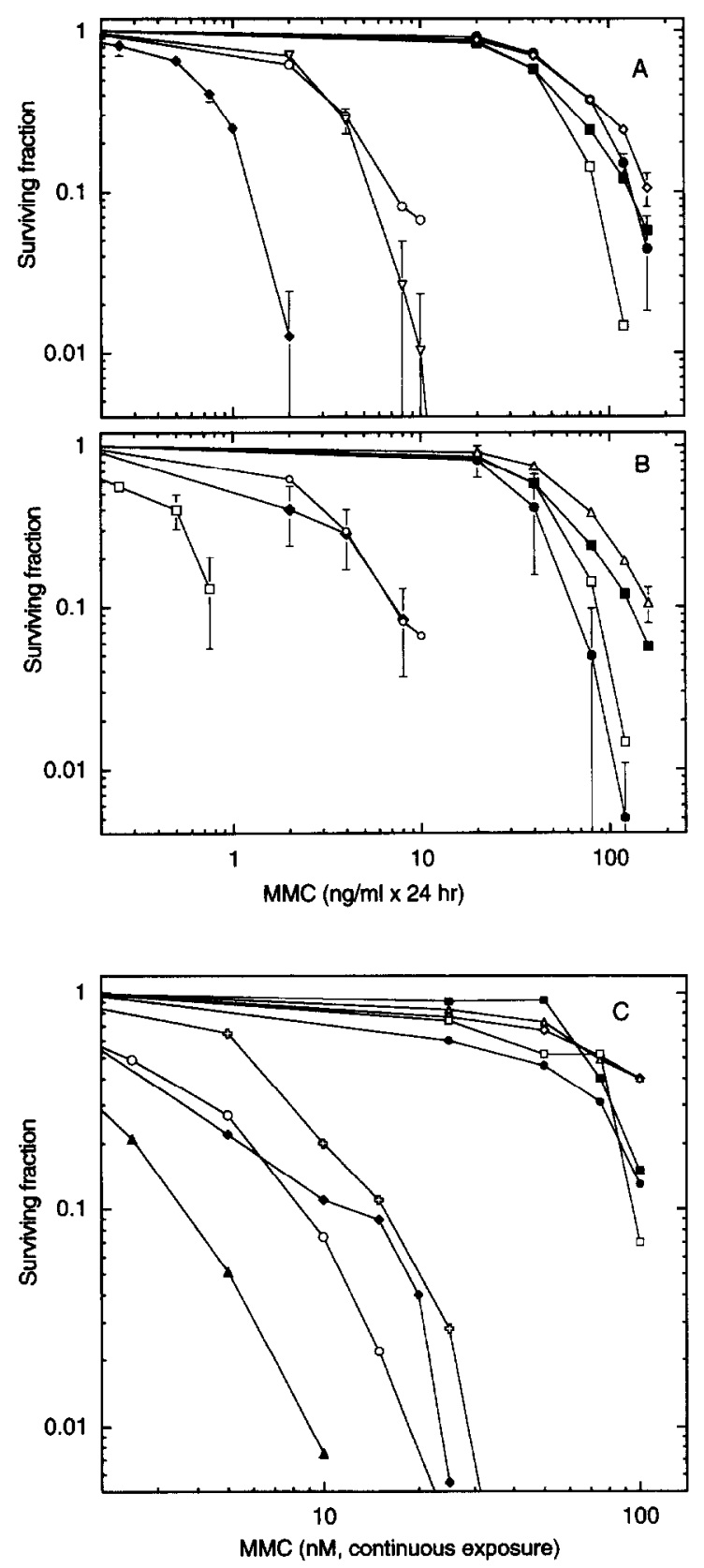

Fig. 2. Complementation analysis of UV40 hybridized with MMC-sensitive mutant lines. (A) Symbols: V-C8, ; V-H4, $\nabla$; UV40, O; AA8, $\square$; V79. —: UV40 $\times$ V-H4TOR, O UV40 $\times$ VC8TOR, $\diamond$. (B) Symbols: irs1, $\square$; irs $1 \mathrm{SF}, \diamond$; UV40 $\times$ irs $1 \mathrm{TOR}$, $\triangle$; UV40 $\times$ irs 1 SF TOR, ; UV40, AA8 and V79 as defined in (A). (C) Symtols: MC5TOR, crosses; irs3TOR, ^ ; UVITOR, $\bullet$; UV40 $\times$ irs3TiR, $\diamond$; UV40 $\times$ MC5TOR, $\triangle$; UV40 $\times$ UV1TOR, - other symbuls as defined in (A). Exposure to MMC was for 24 $h$ in (A) and (B); continuous exposure was used in (C).

\subsection{Analysis of incision kinetics following UV irra- diation}

Since UV40 does show substantial UV sensitivity, it seemed possible that it might be partially defective in the ability to remove UV photoproducts by the incision/excision reaction that has now been well characterized in vitro (Mu et al., 1995; Aboussekhra et al., 1995). Break accumulation was examined as a function of UV fluence $\left(1-5 \mathrm{~J} / \mathrm{m}^{2}\right)$ over several hours following exposure in UV40, wild-type AA8 cells, and the repair-deficient mutant UV135 from complementation group 5 (Thompson and Carrano, 1983), which is a homolog of xeroderma pigmentosum group G (O’Donovan and Wood, 1993). AA8 cells showed a high level of incision immediately after irradiation (slightly increased if cells were preincubated with inhibitors). Significant (but much lower) incision activity was detected at $4-5 \mathrm{~h}$ after UV. As expected, UV135 had levels of incision that were only slightly above background (with apparently rather more activity at later times) (Fig. 3A). Incision in UV40 was somewhat lower than that of AA8 at early times but significantly higher than AA8 during the 4-5-h interval (Fig. 3B). The lack of substantial accumulation of breaks in $4 \mathrm{~h}$ without inhibitors indicates that the ligation process is not defective in these cells. These results suggest that repair is initially slower but persists longer in UV40 cells compared with wild-type cells.

\subsection{Removal of pyrimidine( 6-4)pyrimidinone photoproducts}

As an independent measure of repair, we examined the removal of (6-4) photoproducts using specific antibodies (Mitchell et al., 1985). As shown in Fig. 4, there was no significant difference between UV40 and the parental AA8 cells in the kinetics of removal of this photoproduct. These results further confirm that there is no apparent defect in the removal of UV photoproducts in UV40 cells. This conclusion suggests that there is some other kind of defect in the way UV40 responds to DNA damage.

\subsection{Inhibition of DNA replication by UV irradiation}

DNA replication after UV exposure was examined in order to get some insight into the nature of 

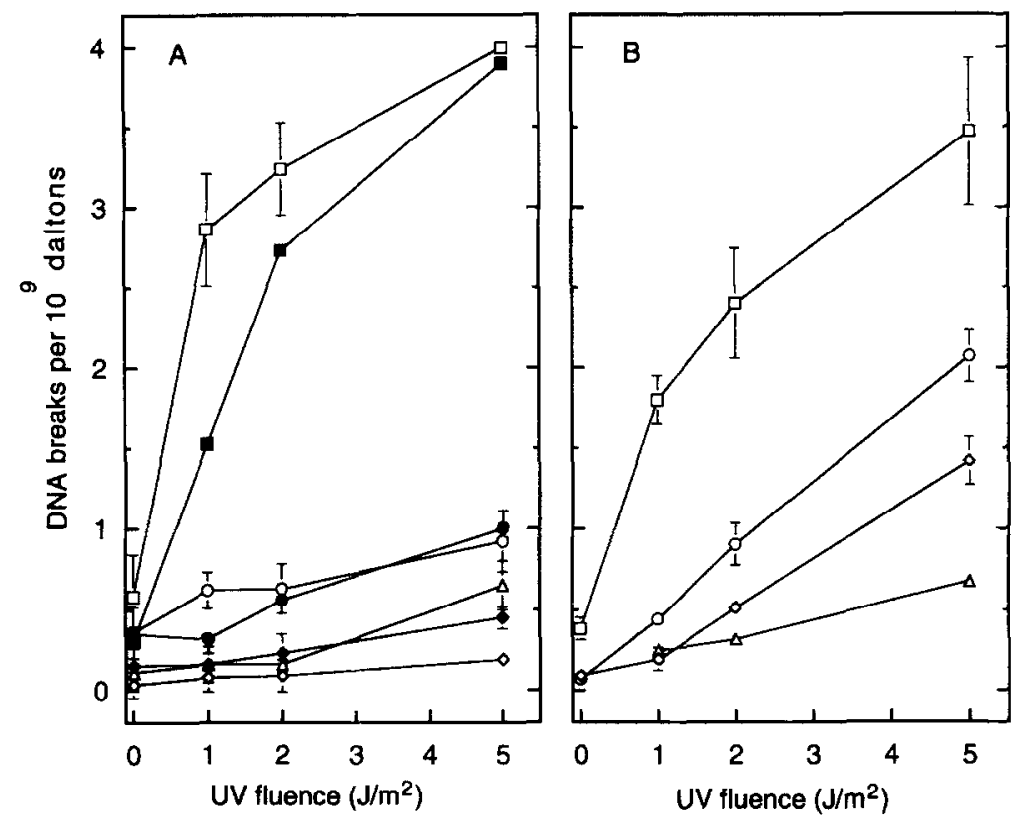

Fig. 3. Accumulation of incision breaks after UV exposure and incubation with DNA synthesis inhibitors. (A) AA8; inhibitors present from $0-0.5 \mathrm{~h}(\mathrm{C})$, or from $0-0.5 \mathrm{~h}$ with a $0.5 \mathrm{~h}$ preincubation $(\square)$, from $4-4.5 \mathrm{~h}(\mathrm{O})$, or $4-5 \mathrm{~h}(\mathrm{O})$. UV $135 ; 0-0.5 \mathrm{~h}(\bigcirc), 4-4.5 \mathrm{~h}(\$), 4-5 \mathrm{~h}$ $(\triangle)$. (B) UV 40 ; inhibitors present from $0-0.5 \mathrm{~h}(\square) .4-4.5 \mathrm{~h}(\diamond), 4-5 \mathrm{~h}(\mathrm{O})$. The triangles represent UV 40 cells incubated for $4 \mathrm{~h}$ without inhibitors.

the biochemical defect in UV40 cells. Wild-type AA8 cells showed a dose-dependent inhibition of DNA replication following exposure to 1,5 or 20 $\mathrm{J} / \mathrm{m}^{2}$ (Fig. 5A). The highest fluence gave a pronounced inhibition to about $30 \%$ with no recovery occurring over a $24-\mathrm{h}$ period. UV40 cells were simi-

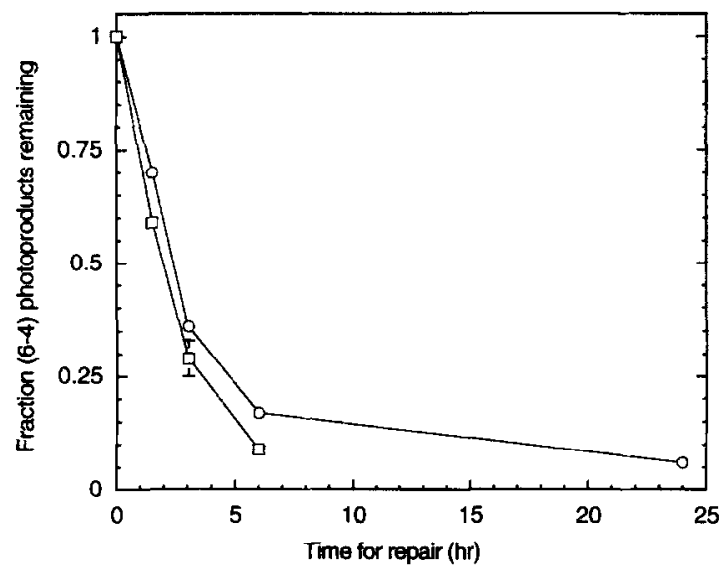

Fig. 4. Kinetics of removal of (6-4) photoproducts after UV irradiation. AA8 ( $\square)$ and UV40 (O). lar to AA8 cells at $1 \mathrm{~J} / \mathrm{m}^{2}$ but considerably more sensitive than AA8 at $5 \mathrm{~J} / \mathrm{m}^{2}$ (Fig. $5 B$ ). By $7 \mathrm{~h}$ after irradiation with $5 \mathrm{~J} / \mathrm{m}^{2}$, AA8 cells had recovered to $100 \%$ but UV40 showed a continued decline. As a negative control, we examined the highly repair-deficient UV135 cells (Fig. 5B). UV135 had significantly more inhibition than UV40 at both fluences tested. We conclude from these data that UV40 is abnormally hypersensitive to inhibition of DNA replication by UV damage although it is somewhat less sensitive than UV135, which does not significantly remove UV photoproducts.

\subsection{Inhibition of RNA synthesis by UV irradiation}

RNA synthesis after UV was studied in AA8, UV40 and UV61 in order to see if UV40 shares the UV sensitivity of RNA synthesis that is present in mutants in rodent complementation group 6 (Cockayne's syndrome group B homolog), which are similar in UV sensitivity to UV40 and which show normal UV excision repair in the unscheduled DNA

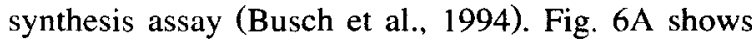


severe inhibition of RNA synthesis in UV61 $18 \mathrm{~h}$ after UV irradiation, with $80 \%$ inhibition at $10 \mathrm{~J} / \mathrm{m}^{2}$. In contrast, AA8 and UV40 both show about $20-25 \%$ inhibition. At lower UV levels, UV40 RNA synthesis levels are slightly lower than AA8 levels, but this does not appear to be significant. Fig. 6B shows inhibition of RNA synthesis in the same three lines at $1,4,8$ and $18 \mathrm{~h}$ after $7.5 \mathrm{~J} / \mathrm{m}^{2}$ of UV. Again. inhibition is extreme in UV61 relative to AA8; UV40 shows a slightly lower level than AA8, but much closer to AA8 than to UV61 and probably not significantly different from AA8. Thus, UV40 shows little or no sensitization in UV inhibition of RNA synthesis compared to AA8.

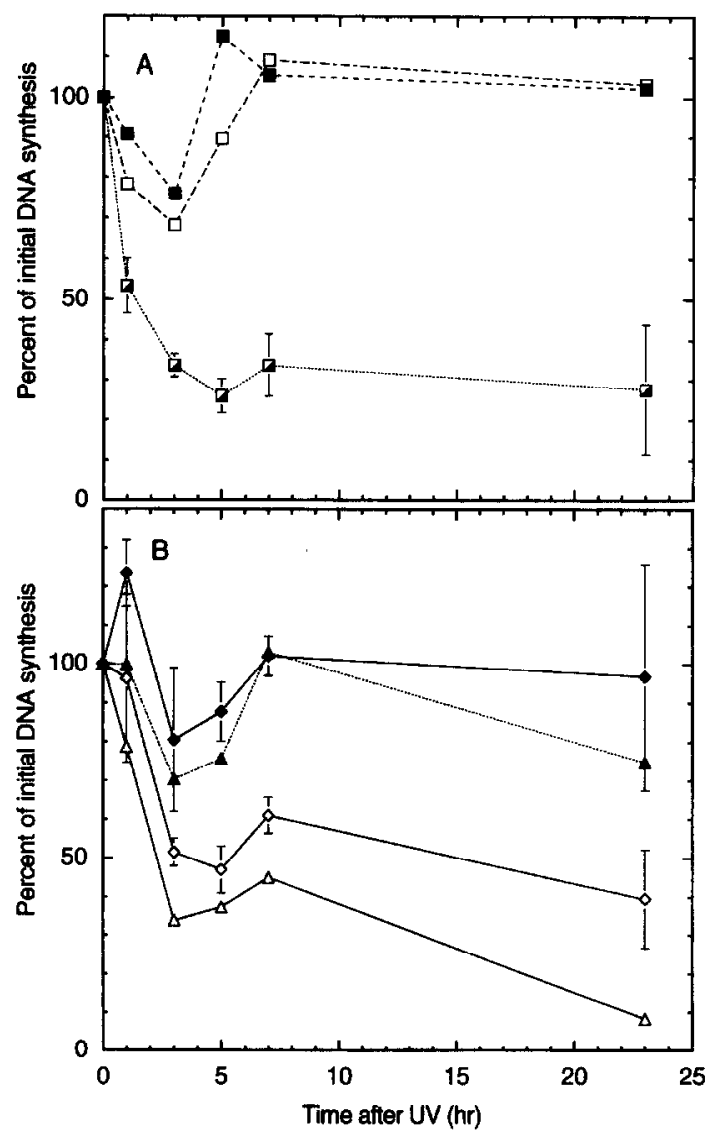

Fig. 5. Inhibition of DNA synthesis by UV irradiation. (A) AA8 cells exposed to 1,5 or $20 \mathrm{~J} / \mathrm{m}^{2}$ (open, closed and half closed squarcs, respectivcly). (B) UV40 exposed to 1 or $5 \mathrm{~J} / \mathrm{m}^{2}$ (closed and open diamonds, respectively); UV135 exposed to 1 or $5 \mathrm{~J} / \mathrm{m}^{2}$ (closed and open triangles, respectively).
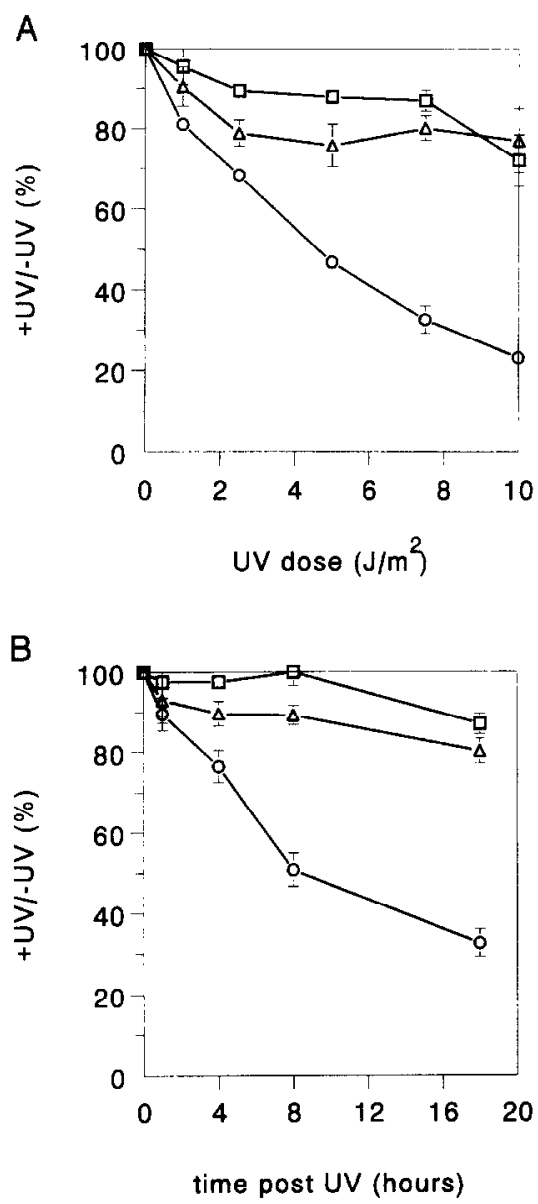

Fig. 6. inhibition of RNA synthesis by UV in AA8 ( $\square$ ), UV40 $(\triangle)$, and UV61 (O). Error bars (mean \pm standard error of mean) omitted when space between bars is smaller than height of symbol (square, triangle, or circle). (A) RNA synthesis with labeling $18 \mathrm{~h}$ after UV irradiation, using different UV levels. (B) RNA synthesis with labeling $1,4,8$ and $18 \mathrm{~h}$ after $7.5 \mathrm{~J} / \mathrm{m}^{2}$ of $\mathrm{UV}$.

\subsection{UV-induced mutations in UV40 versus AA8 cells}

The mutability of UV40 was tested in two independent experiments in different laboratories. In one experiment, mutations at the hprt locus were measured using 6-thioguanine resistance and very long expression times that took into account the slow growth rate of the cells (Fig. 7A). The induced mutation frequencies were similar to what was reported in a previous study for AA8 cells. In the second experiment (Fig. 7B), mutations were mea- 

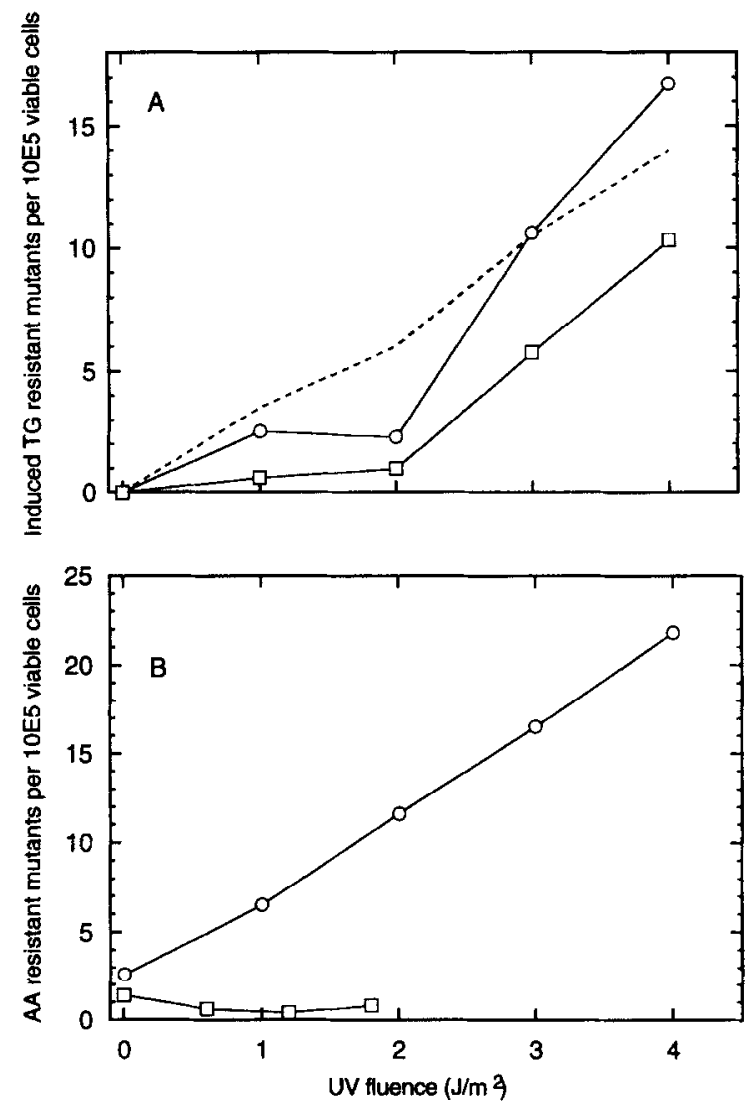

Fig. 7. UV-induced mutagenesis in AA8 and UV40. (A) UV-induced mutations for 6-thioguanine resistance in UV40 after 10 or 12 days expression ( $\square$ and $O$, respectively). Spontaneous frequencies were $7 \times 10^{-6}$ and $9 \times 10^{-6}$ at 10 and 12 days. The dotted line is for previously published data on wild-type AA8 mutability (Thompson et al., 1982). (B) UV-induced mutations for 8 -azaadenine resistance measured after 3 days expression. AA8 cells (circles) and UV40 cells ( $\square$ ). sured at the aprt locus using 8-azaadenine and a short expression time that had previously been shown to be adequate for AA8 cells (Thompson et al., 1980). In this case, efficient mutation induction was seen with AA8 cells, but no significant induction occurred with UV40 cells. To reconcile these collective data we conclude that the UV mutability of UV40 is likely in the normal range but that a protracted expression time is probably needed to detect mutations at the aprt locus.

\subsection{Spontaneous and induced chromosomal aberrations in UV40 's. AA8 cells}

In untreated cultures, the frequency of spontaneous chromosomal aberrations was 6-fold higher than in AA8 cells, with $20 \%$ of the cells showing aberrations. This result indicated a high degree of chromosomal instability (Table 1). Upon exposure to MMC for $24 \mathrm{~h}$, UV40 cells were extremely sensitive. Even though the doses given to UV40 were 10 -fold lower than those given to AA8 cells, higher levels of aberrations were seen in UV40 at all MMC doses. This result is consistent with the survival data (Fig. 1E), which showed that UV40 was at least 10 -fold more sensitive. In comparing the types of aberrations, there were more induced chromatid exchanges than chromatid breaks in both cell lines. Induced chromosome breaks and exchanges occurred at considerably lower levels and were present at approximately equal frequencies in both cell lines. Chromatid gaps, which were not included in the total aberrations, were also seen in all cultures.

Table 1

Mitomycin C clastogenesis of AA8 and UV40 (data are percent of cells with aberrations)

\begin{tabular}{|c|c|c|c|c|c|c|c|c|c|}
\hline $\begin{array}{l}\text { Cell } \\
\text { line }\end{array}$ & $\begin{array}{l}\text { MMC } \\
(\mathrm{ng} / \mathrm{ml})\end{array}$ & $\begin{array}{l}\text { No. cells } \\
\text { scored }\end{array}$ & $\begin{array}{l}\text { Chromatid } \\
\text { gaps }\end{array}$ & $\begin{array}{l}\text { Chromatid } \\
\text { breaks }\end{array}$ & $\begin{array}{l}\text { Chromatid } \\
\text { exchanges }\end{array}$ & $\begin{array}{l}\text { Chromosome } \\
\text { breaks }\end{array}$ & $\begin{array}{l}\text { Chromosome } \\
\text { exchanges }\end{array}$ & $\begin{array}{l}\text { Total } \\
\text { aberrations, } \\
\text { excluding } \\
\text { gaps }\end{array}$ & $\begin{array}{l}\text { Cells with } \\
\text { multiple } \\
\text { aberrations }\end{array}$ \\
\hline \multirow[t]{4}{*}{ AA8 } & 0 & 200 & 9 & 1 & 0.5 & 0.5 & 1.5 & 3.5 & 0 \\
\hline & 20 & 100 & 14 & 1 & 1 & 0 & 3 & 5 & 0 \\
\hline & 40 & 200 & 12 & 21.5 & 32 & 4 & 4.5 & 62 & 11.5 \\
\hline & 80 & 100 & 20 & 19 & 27 & 11 & 15 & 72 & 12 \\
\hline \multirow[t]{4}{*}{ UV40 } & 0 & 200 & 12 & 6.5 & 3 & 2.5 & 8.5 & 20.5 & 0 \\
\hline & 2 & 100 & 16 & 25 & 21 & 4 & 13 & 63 & 0 \\
\hline & 4 & 200 & 33 & 42 & 57 & 6.5 & 11.5 & 117 & 1 \\
\hline & 8 & 100 & 31 & 53 & 100 & 9 & 9 & 171 & 11 \\
\hline
\end{tabular}




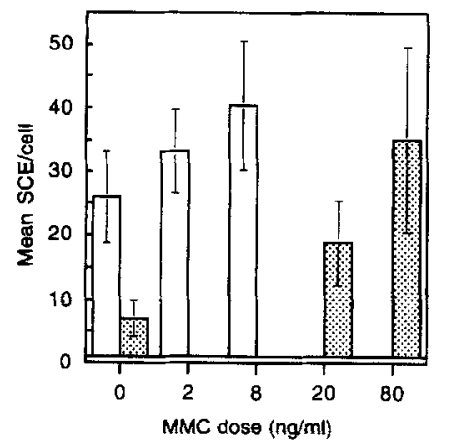

Fig. 8. Spontaneous and MMC-induced sister chromatid exchange in AA8 (shaded bars) and UV40 (open). 25 cells /group, fixation time $43 \mathrm{~h}$.

\subsection{Spontaneous and induced sister chromatid exchanges in UV4O vs. AA8 cells}

Sister chromatid exchange (SCE) is a more subtle, sensitive form of chromosome alteration than aberrations and is induced by a wide variety of DNA damaging agents (Perry and Evans, 1975). UV40 has a very high baseline of SCE, 3.7-fold higher than that of AA8 cells. After exposure to MMC, UV40 showed extreme sensitivity to induction of SCE (Fig. 8). Although the doses given UV40 were 10 -fold lower, the SCE levels, like aberrations, were higher than in AA8 cultures. Thus, UV40 has both a high baseline and high MMC-induced SCE. The high baseline SCE may not be due entirely to spontaneous SCE since it has been shown that the 5 bromodeoxyuridine used in the standard protocol can itself induce a large proportion of the baseline SCE (Pinkel et al., 1985).

\section{Discussion}

In this study, we presented the initial characterization of the UV40 cell line derived from CHO AA8 cells and isolated using the Facility for Automated Experiments in Cell Biology (FAECB). A large collection of FAECB mutants that are defective in nucleotide excision repair was characterized and described during the last 15 years (Busch et al., 1980, 1989, 1994: Thompson et al., 1981; Thompson and Carrano, 1983; Thompson, 1989). Mutant UV40, while showing $\sim 4$-fold UV sensitivity is almost certainly not defective in the NER pathway and must therefore represent a different kind of UV-sensitivity defect. We have shown here that the incision of DNA in UV-irradiated UV40 cells was quite efficient early after irradiation, and between 4 and $5 \mathrm{~h}$ later the levels were actually higher than in AA8 cells (Fig. 3). The kinetics of removal of (6-4) photoproducts were essentially normal (Fig. 4). The RNA study (Fig. 6) shows no evidence for a severe deficiency in preferential repair of actively transcribed genes (Troelstra et al., 1992). The UV-induced mutation frequencies at the hprt locus were in the normal range, which is consistent with there being normal removal of UV photoproducts. The lack of induced mutants at the aprt locus suggests a requirement for a prolonged expression time with this slow-growing mutant (Fig. 6). The CHO-KI mutant UV-I also shows abnormal nucleotide excision repair but appears to have a defect in a postreplication recovery process (Stamato et al., 1981).

The defect in UV40 could lie either in a process that is associated with the bypass of lesions by the DNA replication machinery or in the maturation of newly replicated DNA. Alternatively, the defect might lie in the pathways that regulate the cell cycle in response to DNA damage, e.g., checkpoint controls. The DNA synthesis inhibition data (Fig. 5) may give some clues since the response of UV40 is clearly abnormal. At $5 \mathrm{~J} / \mathrm{m}^{2}$ the pattern of inhibition in UV40 more closely resembled that of an NER-deficient mutant (UV135) than that of wild-type cells. This behavior suggests that UV40 has a substantial UV-induced block to DNA replication. Such a block might conceivably arise if the normally efficient bypass of lesions during replication were diminished or possibly if a minor subset of the UV photoproducts were not susceptible to repair. It is noteworthy that a fluence of $1 \mathrm{~J} / \mathrm{m}^{2}$ incudes $\sim 10^{4}$ photoproducts per cell, which causes little lethality in extremely repair-deficient cells, e.g., XPA or $\mathrm{CHO}$ UV 135. This consideration emphasizes that normal cells can carry a substantial burden of unrepaired damage that the DNA replication and transcription machinery tolerate without lethal consequences. Blockage of DNA replication at lesions might also account for the somewhat delayed removal of lesions seen at $4-5$ h (Fig. 3), presumably mostly cyclobu- 
tane dimers, if such blocks were to prevent access to the photoproducts by the DNA repair complexes.

The profile of mutagen hypersensitivity can also provide clues as to the nature of the defect in a mutant. UV40 displays a broad spectrum of hypersensitivity that is rather similar to that of the V79 mutant irs1 (Jones et al., 1987) and somewhat similar to that of irs1SF, which has less hypersensitivity to (m)ethyl methanesulfonate and UV than UV40. but more hypersensitivity to MMC. The cDNAs that correct irs1 and irs1SF (designated XRCC2 and $X R C C 3$, respectively) have been cloned and sequenced (Tebbs et al., 1995; L. Thompson, N. Liu, J. Lamerdin, and A. Carrano, unpublished results), but the biochemical functions encoded by these genes are currently unknown. The high spontaneous chromosomal aberrations (20\%) in UV40 also resemble the increase seen in irslSF, but the high baseline SCE does not since irs ISF has normal SCE (Fuller and Painter, 1988). irs 1 and UV40 have in common a predominance of chromatid-type aberrations after MMC treatment, with chromatid exchanges being particularly prevalent. The XRCC1 mutant EM9 has 10-fold elevated SCE compared with $\sim$ 4-fold elevation in UV40. UV40 grows rather slowly and has reduced plating efficiency, additional features that are prominent in irs 1 SF. These similarities suggest that the defect in UV40 might lie in the same pathway as the defect in irsl and/or irs ISF, but the phenotypes of these three mutants are distinctly different. It also should be noted that irs1, irs1SF, UV40 and V-C8 all share extreme MMC sensitivity, moderate UV sensitivity, and chromosomal instability.

The genetic complementation analysis based on the sensitivity of hybrid cells to MMC points to UV40 being a new group that is distinct from the other mutants tested (UV-1, MC5, irs1SF, irs1, irs3, $\mathrm{V}-\mathrm{C} 8$ and $\mathrm{V}-\mathrm{H} 4)$. Additional mutants that have less extreme MMC hypersensitivity [MMCl, MMC3, MMC4 and MMS2 (Robson et al., 1985; Robson and Hickson, 1989)] were not tested, but these mutants display little or no UV or X-ray hypersensitivity. Therefore, it seems unlikely that UV40 is defective in the same genetic locus as one of these latter mutants.

The question arises as to whether the defect in UV40 might correspond to that in a human DNA repair disorder. The hypersensitivity to MMC and elevated spontaneous chromosomal aberrations are characteristic of Fanconi anemia cells (dos Santos et al., 1994), of which one complementation group is homologous to V-H4 (Arwert et al., 1991), but other fcatures such as the elevated SCE and the high sensitivity to (m)ethylating agents would argue against this possibility. However, not all complementation groups of Fanconi anemia have been well characterized, and heterogeneity may exist among the groups. It also could be a Roberts syndrome homolog (Burns and Tomkins, 1989), although Roberts syndrome has other cytogenetic abnormalities. Since a cDNA (designated XRCC9) that corrects UV40 has been cloned recently (N. Liu and L. Thompson, unpublished results), it will be possible to test this sequence for its ability to correct the various complementation groups of Fanconi anemia cells.

\section{Acknowledgements}

Supported by the Armed Forces Institute of Pathology; the American Registry of Pathology; Dutch Cancer Society grant No. IKW 90-03, Cancer Research Campaign; Scottish Office Agriculture and Fisheries Dept; the National Institutes of Health (grant nos. GM22021, CA04484 and RR00961); the National Research Council of Italy (C.N.R. Target Project 'Ingegneria Genetica'); and the North West Cancer Research Fund, and performed under the auspices of the U.S. Department of Energy by Lawrence Berkeley Laboratory grant number 7134700, and Lawrence Livermore National Laboratory contract \#W-7405-ENG-48. We appreciate the advice and assistance of Donald A. Glaser and technical support offered by Jerry Adams, Hazel Bell, John L. Couch, Maryam Neishabury, Alex Para, Helen Stouffer, and Lisa Wills. This manuscript is dedicated to Lloyd 'Bud' Fuller.

The opinions or assertions stated herein are the private views of the authors, and are not to be construed as representing the views of the Amcrican Registry of Pathology, the Armed Forces Institute of Pathology, the Department of the Army, the Department of Environmental and Toxicologic Pathology, Lawrence Livermore National Laboratory, the U.S. 


\section{Department of Defense, or the U.S. Department of Energy.}

\section{References}

Aboussekhra, A., M. Biggerstaff, M.K.K. Shivji, J.A. Vilpo, V. Moncollin, V.N. Podust, M. Protić, U. Hübscher, J.-M. Egly and R.D. Wood (1995). Mammalian DNA nucleotide excision repair reconstituted with purified protein components, Cell, 80 , $859-868$

Arwert, F., M. Rooimans, A. Westerveld, J.W.I.M Simons and M.Z. Zdzienicka (1991) The Chinese hamster cell mutant V-H4 is homologous to Fanconi's anemia (complementation group A), Cytogenet. Cell Genet., 56, 23-26.

Burns, M.A. and D.J. Tomkins (1989) Hypersensitivity to mitomycin C cell-killing in Roberts syndrome fibroblasts with, but not without, the heterochromatin abnormality, Mutation Res., 216, 243-249.

Busch, D.B. (1980) Large-scale isolation of DNA repair mutants of Chinese hamster ovary cells, Dissertation, University of California, Berkeley, University Microfilms International, Ann Arbor.

Busch. D.B., J.E. Cleaver and D.A. Glaser (1980) Large-scale isolation of UV-sensitive clones of $\mathrm{CHO}$ cells. Somat. Cell Genet., 6, 407-418.

Busch, D., C. Greiner, K. Lewis, R. Ford, G. Adair and L.H. Thompson (1989) Summary of complementation groups of UV-sensitive CHO cell mutants isolated by large scale screening, Mutagenesis, 4, 349-354.

Busch, D.B., C. Greiner, K.L. Rosenfeld, R. Ford. J. de Wit. J.H.J. Hoeijmakers and L.H. Thompson (1994) Complementation group assignments of moderately $\mathrm{UV}$-sensitive $\mathrm{CHO}$ mutants isolated by large-scale screening (FAECB), Mutagenesis. 9. 301-306.

Collins, A.R. (1993) Mutant rodent cell lines sensitive to ultraviolet light, ionizing radiation and cross-linking agents: a comprehensive survey of genetic and biochemical characteristics, Mutation Res., 293, 99-118.

Collins, A. and D.J. Oates (1987) Hydroxyurea: effects on deoxyribonucleotide pool sizes correlated with effects on DNA repair in mammalian cells, Eur. J. Biochem., 169, 299-305.

Collins, A., C. Jones and C. Waldren (1982) A survey of DNA repair incision activities after ultraviolet irradiation of a range of human, hamster, and hamster-human hybrid cell lines, J. Cell Sci.., 56, 423-440.

dos Santos, C.C., H. Gavish and M. Buchwald (1994) Fanconi anemia revisited: old ideas and new advances, Stem Cells, 12 . $142-153$.

Fuller, L.F. and R.B Painter (1988) A Chinese hamster ovary cell line hypersensitive to ionizing radiation and deficient in repair replication, Mutation Res., 193, 109-121.

Harris, M. (Jan 23, 1980a) US cuts off funds to UC scientist, San Francisco Chronicle, 116th year, No. 6, p. 4.

Harris, M. (April 14, 1980b) US cuts off funds to UC scientist, Current Contents Life Sciences, 23, (15), 17.

Hoy, C.A., L.H. Thompson, E.P Salazar and S.A. Stewart (1985)
Different genetic alterations underlie dual hypersensitivity of CHO mutant UV-1 to DNA methylating and cross-linking agents, Somat. Cell Mol. Genet., 11, 523-532.

Jones, N.J. (1994) Genetic analysis of mitomycin C-hypersensitive Chinese hamster cell mutants, Mutagenesis, 9, 477-482.

Jones, N.J., R. Cox and J. Thacker (1987) Isolation and crosssensitivity of X-ray-sensitive mutants of V79-4 hamster cells. Mutation Res., 183, 279-286.

Jones, N.J., R. Cox and J. Thacker (1988) Six complementation groups for ionising-radiation sensitivity in Chinese hamster cells, Mutation Res., 193, 139-144.

Jones, N.J., S.A. Stewart and L.H. Thompson (1990) Biochemical and genetic analysis of the Chinese hamster mutants irs 1 and irs2 and their comparison to cultured ataxia telangiectasia cells, Mutagenesis, 5, 15-23.

Jones, N.J., S. Ellard, R. Waters and E.M. Parry (1993) Cellular and chromosomal hypersensitivity to DNA crosslinking agents and topoisomerase inhibitors in the radiosensitive Chinese hamster irs mutants: phenotypic similarities to ataxia telangiectasia and Fanconi's anaemia cells, Carcinogenesis, 14 , 2487-2494.

Lommel, L. and P.C. Hanawalt (1991) The genetic defect in the Chinese hamster ovary cell mutant UV61 permits moderate selective repair of cyclobutane pyrimidine dimers in an expressed gene, Mutation Res.. 255, 183-191.

Mayne L.V. and A.R. Lehmann (1982) Failure of RNA synthesis to recover after UV irradiation: an early defect in cells from individuals with Cockayne's syndrome and xeroderma pigmentosum. Cancer Res., 42, 1473-1478.

Mitchell, D.L., C.A. Haipek and J.M. Clarkson (1985) (6-4) photoproducts are removed from the DNA of UV-irradiated mammalian cells more efficiently than cyclobutane dimers, Mutation Res., 143, 109-112.

Mitchell, D.L., R.M. Humphrcy, G.M. Adair. L.H. Thompson and J.M. Clarkson (1988) Repair of (6-4) photoproducts correlates with split-dose recovery in UV-irradiated normal and hypersensitive rodent cells, Mutation Res. 193, 53-63.

Mu, D., C.-H. Park, T. Matsunaga, D.S. Hsu, J.T. Reardon and A. Sancar (1995) Reconstitution of human DNA repair excision nuclease in a highly defined system. J. Biol. Chem., 270 . 2415-2418.

Mudgett, J.S. and M.A. MacInnes (1990) Isolation of the functional human DNA excision repair gene ERCC5 by intercosmid recombination. Genomics, 8, 623-633.

O'Donovan, A. and R.D. Wood (1993) Identical defects in DNA repair in xeroderma pigmentosum group $\mathrm{G}$ and rodent ERCC group 5. Nature, 363, 185-188.

Overkamp, W.J.I., M.A. Rooimans, I. Neuteboom, P. Telleman, F. Arwert and M.Z. Zdzienicka (1993) Genetic diversity of mitomycin C-hypersensitive Chinese hamster cell mutants: a new complementation group with chromosomal instability, Somat. Cell Mol. Genet., 19, 431-437.

Perry. P. and H.J. Evans (1975) Cytological detection of mutagen-carcinogen exposure by sister chromatid exchange, Nature, 258, 121-125.

Perry, P. and S. Wolff (1974) New Giemsa method for the differential staining of sister chromatids, Nature, 251, 156-8. 
Petit, C. (January 23, 1980) A one-eyed seeker of cells, San Francisco Chronicle, 116th year, No. 6, p. 4.

Pinkel, D., L.H. Thompson, J.W. Gray and M. Vanderlaan (1985) Measurement of sister chromatid exchanges at very low bromodeoxyuridine substitution levels using a monoclonal antibody in Chinese hamster ovary cells, Cancer Res., 45, 5795 5798.

Riboni, R., E. Botta, M. Stefanini, M. Numata and A. Yasui. (1992) Identification of the eleventh complementation group of UV-sensitive excision repair-defective rodent mutants, Cancer Res., 52, 6690-6691.

Robson, C.N, and I.D. Hickson (1989) Isolation of alkylating agent-sensitive Chinese hamster ovary cell lines. Carcinogenesis, 8, 601-605.

Robson, C.N., A.L. Harris and I.D. Hickson (1985) Isolation and characterization of Chinese hamster ovary cell lines sensitive to mitomicin C and bleomycin, Cancer Res., 45, 5304-5309.

Squires, S., R.T. Johnson and A.R. Collins (1982) Initial rates of DNA incision in UV-irradiated human cells Differences between normal, xeroderma pigmentosum and tumour cells. Mutation Res., 95, 389-404.

Stamato, T.D., L. Hinkle, A.R.S. Collins and C.A. Waldren (1981) Chinese hamster ovary mutant UV-1 is hypomutable and defective in a postreplication recovery process. Somat. Cell Genet., 7, 307-320.

Stefanini, M., A.R. Collins, R. Riboni, M. Klaude, E. Butta, D.L. Mitchell and F. Nuzzo (1991) Novel Chinese hamster ultraviolet-sensitive mutants for excision repair form complementation groups 9 and 10, Cancer Res., 51, 3965-3971.

Studzian, K., P. Telleman, G.P. van der Schans and M. Zdzienicka (1994) Mutagenic response and repair of cis-DDP-induced DNA cross-links in the Chinese hamster V79 cell mutant $\mathrm{V}-\mathrm{H} 4$ which is homologous to Fanconi anemia (group A), Mutation Res., 314, 115-120.

Tebbs, R.S., Y. Zhao, J.D. Tucker, J.B. Scheerer, M.J. Siciliano, M. Hwang, N. Liu. R.J. Legerski and L.H. Thompson (1995) Correction of chromosomal instability and sensitivity to diverse mutagens by a cloned cDNA of the XRCC3 DNA repair gene. Proc. Natl. Acad. Sci. USA, 92, 6354-6358.

Thompson, L.H. (1989) Special anniversary invited review series. Somatic cell genetics approach to dissecting mammalian DNA repair, Environ. Mol. Mutagen., 14, 264-281.

Thompson, L.H. and A.V. Carrano (1983) Analysis of mammalian cell mutagenesis and DNA repair using in vitro selected $\mathrm{CHO}$ cell mutants, in: E.C. Friedberg and B.A. Bridges (Eds.), Cellular Responses to DNA Damage, Vol. 11, Alan R. Liss, New York, pp. 125-143.
Thompson, L.H., S. Fong and K. Brookman (1980) Validation of conditions for efficient detection of HPRT and APRT mutations in suspension-cultured Chinese hamster ovary cells, $\mathrm{Mu}$ tation Res., 74, 21-36.

Thompson, L.H., D.B. Busch, K. Brookman, C.L. Mooney and D.A. Glaser (1981) Genetic diversity of UV-sensitive DNA repair mutants of Chinese hamster ovary cells, Proc. Natl. Acad. Sci. USA, 78, 3734-37.

Thompson, L.H., K.W. Brookman, L.E. Dillehay, C.L. Mooney and A.V. Carrano (1982) Hypersensitivity to mutation and sister-chromatid exchange induction in $\mathrm{CHO}$ cell mutants defective in incising DNA containing UV lesions. Somat. Cell Genet., 8, 759-773.

Thompson, L.H., E.P. Salazar, K.W. Brookman, C.C. Collins, S.A. Stewart, D.B. Busch and C.A. Weber (1987) Recent progress with the DNA repair mutants of Chinese hamster ovary cells, J. Cell Sci., 6 (Suppl.), 97-110.

Thompson, L.H., T. Shiomi, E.P. Salazar and S.A. Stewart (1988) An eighth complementation group of rodent cells hypersensitive to ultraviolet radiation, Somat. Cell Mol. Genet., 14, $605-612$.

Thompson, L.H., D.L. Mitchell, J.D. Regan. S.D. Bouffler, S.A. Stewart, W.L. Carrier, R.S. Nairn and R.T. Johnson (1989) CHO mutant UV61 removes (6-4) photoproducts but not cyclobutane dimers, Mutagenesis, 4, 140-146.

Thompson, L.H., K.W. Brookman, C.A. Weber, E.P. Salazar, J.T. Reardon, A. Sancar, Z. Deng and M.J. Siciliano (1994) Molecular cloning of the human nucleotide-excision-repair gene ERCC4, Proc. Natl. Acad. Sci. USA, 91, 6855-6859.

Troelstra, C.H., H. Odijk, J. de Wit, A. Westerveld, L.H. Thompson, D. Bootsma and J.H. Hoeijmakers (1990) Molecular cloning of the human DNA excision repair gene ERCC-6, Mol. Cell Biol, 10, 5806-5813.

Troelstra, C., A. van Gool, J. de Wit, W. Vermeulen, D. Boolsma and J.H.J. Hoeijmakers (1992) ERCC6, a member of a subfamily of putative helicases, is involved in Cockayne's syndrome and preferential repair of active genes, Cell, 71, 939953.

Zdzienicka, M.Z., G.P. van der Schans and J.W.I.M. Simons (1988) Identification of a new seventh complementation group of UV-sensitive mutants in Chinese hamster cells, Mutation Res., 194, 165-170.

Zdzienicka, M.. F. Arwert, I. Neuteboom, M. Rooimans and J.W.I.M. Simons (1990) The Chinese hamster V79 cell line mutant $\mathrm{V}-\mathrm{H} 4$ is phenotypically like Fanconi anemia cells, Somat. Cell Mol. Genet. 16, 575-581. 